\title{
HUBUNGAN ANTARA ASUPAN PROTEIN DAN ZAT BESI DENGAN KADAR HEMOGLOBIN MAHASISWA PROGRAM STUDI PENDIDIKAN DOKTER ANGKATAN 2013 FAKULTAS KEDOKTERAN UNIVERSITAS SAM RATULANGI
}

\author{
${ }^{1}$ Shanon G. Matayane \\ ${ }^{2}$ Alexander S. L Bolang \\ ${ }^{2}$ Shirley E. S Kawengian
}

\author{
${ }^{1}$ Kandidat Skripsi Fakultas Kedokteran Universitas Sam Ratulangi Manado \\ ${ }^{2}$ Bagian Ilmu Gizi Fakultas Kedokteran Universitas Sam Ratulangi Manado \\ Email: shanonensha@gmail.com
}

\begin{abstract}
Hemoglobin is the oxygen-carrying compound in red blood cells. Someone hemoglobin level scan be affected by several other factors: age, gender, systemic disease and diet. Nutrient intake plays a role in the formation of redblood cells. Disruption of the formation of redblood cells could be due to lack of food consumed contains essential nutrients such as iron, folic acid, vitamin B12, protein, vitamin C and other important nutrients. This study aims to determine the relation ship between the intake of protein and iron in hemoglobin level student of medical education force in 2013 Sam Ratulangi University School of Medicine. The design is an analytical study using cross-sectional approach. The study sample is determined and carried out systematic random sampling proportional to the gender of men and women and who met the inclusion criteria sample amounted to75 people. Data were collected through questionnaires and food recall by measuring hemoglobin levels, then the data were analyzed using the Spearman rank test. Protein intake is less $52.0 \%, 16.0 \%$ protein and enough protein intake over $32.0 \%$. Iron intake less than $98.7 \%$ and $1.3 \%$ more protein intake. Normal hemoglobin levels of $93.3 \%$ and $6.7 \%$ is not normal. Conclusion: The results of the study with Spearman rank test for protein and hemoglobin levels obtained pvalue is $0.138(p>\alpha=0.05)$ which means that there is no significant relationship between iron intake with hemoglobin levels. For intake of iron and hemoglobin levels obtained $p$ value is $0.198(\mathrm{p}>\alpha=0.05)$, which means there is nosignificant relationship between iron intake with hemoglobin levels. Keywords: Proteinintake, intake ofIron, Hemoglobin.
\end{abstract}

\begin{abstract}
Abstrak: Hemoglobin merupakan senyawa pembawa oksigen pada sel darah merah. Kadar hemoglobin seseorang dapat dipengaruhi oleh beberapa faktor lain: usia, jenis kelamin, penyakit sistemik dan pola makan. Asupan zat gizi berperan dalam pembentukan sel darah merah. Terganggunya pembentukan sel darah merah bisa disebabkan makanan yang dikonsumsi kurang mengandung zat gizi penting seperti besi, asam folat, vitamin B12, protein, vitamin $C$ dan zat gizi penting lainnya. Penelitian ini bertujuan untuk mengetahui hubungan antara asupan protein dan zat besi dengan kadar hemoglobin mahasiswa program studi pendidikan dokter angkatan 2013 Fakultas Kedokteran Universitas Sam Ratulangi. Rancangan penelitian ini bersifat analitik dengan menggunakan pendekatan cross-sectional. Sampel penelitian ini ditentukan secara systematic random sampling dan dilakukan proposional untuk jenis kelamin laki-laki dan perempuan dan sampel yang memenuhi kriteria inklusi berjumlah 75 orang. Data dikumpulkan melalui kuesioner food recall dan melalui pengukuran kadar hemoglobin, kemudian data dianalisis dengan menggunakan uji spearman rank. Asupan protein yang kurang 52,0\%, asupan protein cukup 16,0\% dan asupan protein
\end{abstract}


lebih 32,0\%. Asupan zat besi kurang 98,7\% dan asupan protein lebih 1,3\%. Kadar hemoglobin normal 93,3\% dan 6,7\% tidak normal. Simpulan: hasil penelitian dengan uji spearman rank untuk asupan protein dan kadar hemoglobin diperoleh nilai $p$ yaitu 0,138 $(\mathrm{p}>\alpha=0,05)$ yang berarti tidak ada hubungan yang bermakna antara asupan zat besi dengan kadar hemoglobin. Untuk asupan zat besi dan kadar hemoglobin diperoleh nilai $p$ yaitu 0,198 $(p>\alpha=0,05)$ yang berarti tidak ada hubungan yang bermakna antara asupan zat besi dengan kadar hemoglobin.

Kata kunci: Asupan Protein, Asupan Zat Besi, Hemoglobin.

Hemoglobin merupakan senyawa pembawa oksigen pada sel darah merah. Hemoglobin dapat diukur secara kimia dan jumlah $\mathrm{Hb} / 100 \mathrm{ml}$ darah dapat digunakan sebagai indeks kapasitas pembwa oksigen pada darah. ${ }^{1}$ Kadar hemoglobin seseorang dapat dipengaruhi oleh beberapa faktor antara lain: usia, jenis kelamin, penyakit sistemik dan pola makan. ${ }^{2}$

Kadar hemoglobin dalam tubuh harus pada nilai yang normal. Apabila kadar hemoglobin menurun akan mengakibatkan terjadinya anemia. Anemia adalah suatu keadaan dengan kadar hemoglobin lebih rendah dari normal, anemia juga berarti suatu kondisi ketika terdapat defisiensi ukuran/jumlah eritrosit atau kandungan hemoglobin. ${ }^{3}$

Anemia merupakan masalah kesehatan dan memiliki prevalensi yang tinggi di berbagai negara di dunia. Data WHO dalam Worldwide Prevalence of Anemia menunjukan bahwa total keseluruhan penduduk dunia yang menderita anemia adalah 1,62 miliar orang dengan prevalensi usia pra sekolah $47,4 \%$, usia sekolah $25,4 \%$, wanita usia subur $41,8 \%$ dan pria $12,7 \% .{ }^{4}$

Asupan zat gizi berperan dalam pembentukan sel darah merah. Asupan zat gizi yang tidak mencukupi dapat mengganggu pembentukan sel darah merah. Padahal umur sel darah merah di dalam darah harus selalu dipertahankan cukup banyak. Terganggunya pembentukan sel darah merah bisa disebabkan makanan yang dikonsumsi kurang mengandung zat gizi terutama zat-zat gizi penting seperti besi, asam folat, vitamin B12, protein, vitamin C dan zat gizi penting lainnya. ${ }^{5}$

Berdasarkan hasil penelitian yang dilakukan oleh Teti di Asrama SMAN
Tinggi Moncong menunjukan bahwa ada 92,8\% siswa memiliki rata-rata asupan protein lebih dan 52,6\% siswa memiliki rata-rata asupan zat besi kurang. ${ }^{6}$

\section{METODE PENELITIAN}

Penelitian ini bersifat analitik dengan menggunakan pendekatan cross-sectional dan dilaksanakan di Manado selama bulan September 2013 - Januari 2014. Sampel penelitian ini ditentukan secara systematic random sampling dan dilakukan proposional untuk jenis kelamin laki-laki dan perempuan dan sampel yang memenuhi kriteria inklusi berjumlah 75 orang. Data dikumpulkan melalui kuesioner food recall dan melalui pengukuran kadar hemoglobin, kemudian data dianalisis dengan menggunakan uji spearman rank.

\section{HASIL PENELITIAN}

\section{Karakteristik Responden}

Berdasarkan jenis kelamin, jenis kelamin perempuan memiliki distribusi tertinggi yaitu sebesar 65\% sedangkan lakilaki sebesar 35\%. Berdasarkan umur, responden dengan umur 18 tahun memiliki distribusi tertinggi yaitu sebesar 67\%. Responden yang tinggal dengan orang tua dan kos memiliki distribusi yang hampir sama, dimana yang tinggal dengan orang tua sebesar 52\% dan kos sebesar $48 \%$.

Berdasarkan pekerjaan orang tua responden, ayah responden yang bekerja sebagai PNS memiliki distribusi tertinggi yaitu sebesar 47\%, sama halnya ibu responden yang bekerja sebagai PNS sebesar $45 \%$. 


\section{Asupan Protein}

Distribusi responden terhadap asupan protein dapat dilihat pada tabel 1 . Berdasarkan distribusi responden terhadap asupan protein menunjukan bahwa responden dengan asupan protein kurang memiliki distribusi tertinggi pada penelitian ini yaitu sebesar 52\% dan responden dengan asupan protein cukup memiliki distribusi paling rendah yaitu sebesar $16 \%$.

Tabel 1. Distribusi responden terhadap asupan protein

\begin{tabular}{cccc}
\hline \multirow{2}{*}{ Asupan Protein } & \multicolumn{2}{c}{ Semua Responden } \\
\cline { 3 - 4 } & Kurang & 39 & $\%$ \\
\hline \multirow{3}{*}{ Asupan Protein } & Cukup & 12 & 16 \\
& Lebih & 24 & 32 \\
\hline
\end{tabular}

\section{Asupan Zat Besi}

Distribusi responden terhadap asupan zat besi dapat dilihat pada Tabel 2 . Berdasarkan distribusi responden terhadap asupan zat besi menunjukan bahwa responden dengan asupan zat besi kurang memiliki distribusi tertinggi pada penelitian ini yaitu sebesar 98,7\% dan responden dengan asupan protein cukup memiliki distribusi paling rendah yaitu sebesar $0 \%$.

Tabel 2. Distribusi responden terhadap asupan zat besi

\begin{tabular}{cccc}
\hline \multirow{2}{*}{ Asupan Zat Besi } & \multicolumn{2}{c}{ Semua Responden } \\
\cline { 3 - 4 } & Kurang & 74 & $\%$ \\
\hline \multirow{3}{*}{ Asupan Zat Besi } & Cukup & 0 & 0 \\
& Lebih & 1 & 1,3 \\
\hline
\end{tabular}

\section{Kadar Hemoglobin}

Distribusi responden terhadap status hemoglobin dapat dilihat pada tabel 3 . Berdasarkan distribusi responden terhadap status hemoglobin menunjukan bahwa responden dengan status hemoglobin normal memiliki distribusi tertinggi pada penelitian ini yaitu sebesar 93,3\% dan responden dengan status hemoglobin tidak normal memiliki distribusi paling rendah yaitu sebesar $6,7 \%$.

Tabel 3. Distribusi responden terhadap status hemoglobin

\begin{tabular}{ccc}
\hline \multirow{2}{*}{ Status Hemoglobin } & \multicolumn{2}{c}{ Semua Responden } \\
& $\mathrm{N}$ & $\%$ \\
\hline Normal & 70 & 93,3 \\
Tidak normal & 5 & 6,7 \\
\hline
\end{tabular}

\section{Hubungan Antara Asupan Protein Dan Zat Besi Dengan Kadar Hemoglobin}

Distribusi responden terhadap status hemoglobin berdasarkan asupan protein dapat dilihat pada Tabel 4. Responden dengan asupan protein kurang yang memiliki status hemoglobin normal memiliki distribusi tertinggi yaitu sebesar 92,3\% sama halnya status hemoglobin tidak normal yang juga didominasi oleh responden dengan asupan protein kurang yaitu sebesar 7,7\%. Distribusi responden terhadap status hemoglobin berdasarkan asupan zat besi dapat dilihat pada Tabel 5 . Responden dengan asupan zat besi kurang yang memiliki status hemoglobin normal memiliki distribusi tertinggi yaitu sebesar 93,2\% sama halnya status hemolgobin tidak normal yang juga didominasi oleh responden dengan asupan zat besi kurang yaitu sebesar 6,8\%.

Hasil uji spearman rank, hubungan asupan protein dan zat besi dengan kadar hemoglobin dapat dilihat pada Tabel 6 . Hasil uji tersebut menunjukan bahwa tidak ada hubungan yang bermakna antara asupan protein dengan kadar hemoglobin dimana nilai $\mathrm{r}=0,173$ dan $\mathrm{p}=0,138>\alpha=0,05$. Asupan zat besi dengan kadar hemoglobin juga menunjukan tidak ada hubungan yang bermakna dimana nilai $\mathrm{r}=0,150$ dan $\mathrm{p}=$ $0,198>\alpha=0,05$ 
Jurnal e-Biomedik (eBM), Volume 2, Nomor 3, November 2014

Tabel 4. Distribusi responden terhadap status hemoglobin berdasarkan asupan protein

\begin{tabular}{ccccccc}
\hline & \multicolumn{9}{c}{ Status Hemoglobin } & \multicolumn{2}{c}{ Total } \\
\hline Asupan Protein & \multicolumn{2}{c}{ Normal } & \multicolumn{2}{c}{ Tidak normal } & \multicolumn{2}{c}{} \\
\cline { 2 - 8 } & $\mathrm{n}$ & $\%$ & $\mathrm{~N}$ & $\%$ & $\mathrm{n}$ & $\%$ \\
\hline Kurang & 36 & 92,3 & 3 & 7,7 & 39 & 100 \\
Cukup & 12 & 100 & 0 & 0 & 12 & 100 \\
Lebih & 22 & 91,7 & 2 & 8,3 & 24 & 100 \\
\hline
\end{tabular}

Tabel 5. Distribusi responden terhadap status hemoglobin berdasarkan asupan zat besi

\begin{tabular}{cccccccc}
\hline & \multicolumn{4}{c}{ Status Hemoglobin } & \multicolumn{2}{c}{ Total } \\
\hline Asupan Zat Besi & \multicolumn{2}{c}{ Normal } & \multicolumn{2}{c}{ Tidak normal } & \multicolumn{3}{c}{} \\
\cline { 2 - 7 } & $\mathrm{n}$ & $\%$ & $\mathrm{~N}$ & $\%$ & $\mathrm{n}$ & $\%$ \\
\hline Kurang & 69 & 93,2 & 5 & 6,8 & 74 & 100 \\
Cukup & 0 & 0 & 0 & 0 & 0 & 0 \\
Lebih & 1 & 100 & 0 & 0 & 1 & 100 \\
\hline
\end{tabular}

Tabel 6. Hubungan antara asupan protein dan zat besi dengan kadar hemoglobin

\begin{tabular}{lcc}
\hline Variabel Penelitian & $\boldsymbol{R}$ & $\boldsymbol{p}$ \\
\hline Asupan Protein & 0,173 & 0,138 \\
Kadar Hemoglobin & & \\
Asupan Zat Besi & 0,150 & 0,198 \\
Kadar Hemoglobin & & \\
\hline
\end{tabular}

\section{BAHASAN}

Hasil penelitian ini menunjukan bahwa sebagian besar responden memiliki asupan protein kurang yaitu 52,0\%. Hasil penelitian ini sama dengan hasil penelitian yang dilakukan oleh M. Sadli Umasangaji tahun 2012 pada anggota klub tenis meja di Ternate yang menunjukan bahwa untuk asupan protein, sebagian besar responden memiliki asupan protein kurang yaitu sebesar 90,9\%. ${ }^{7}$ Sementara itu, penelitian ini memiliki hasil yang berbeda dari penelitian yang dilakukan oleh Muchlisa, Citrakesumasari dan Rahayu Indriasari tahun 2013 pada remaja fakultas kesehatan masyarakat di Makasar yang menunjukan bahwa $66,9 \%$ responden memiliki asupan protein yang cukup sedangkan responden yang asupan proteinnya kurang sebanyak $33,1 \%{ }^{8}$

Asupan protein harus dalam batasan yang cukup. Asupan protein yang cukup menunjukan bahwa konsumsi lauk pauk pada umumnya baik karena protein disuplai dari lauk pauk baik hewani maupun nabati. Konsumsi makanan sumber protein dalam jumlah yang cukup setiap hari seperti ikan, daging ayam, telur, tempe dan tahu. Kekurangan protein akan berdampak terhadap pertumbuhan yang kurang baik, daya tahan tubuh menurun, lebih rentan terhadap penyakit, serta daya kreativitas dan daya kerja menurun. Protein secara berlebihan tidak menguntungkan tubuh. Kelebihan protein akan menimbulkan asidosis, dehidrasi, diare, kenaikan amoniak darah, kenaikan ureum darah dan demam.,9

Sebagian responden memiliki asupan zat besi kurang mendominasi pada penelitian ini yaitu sebesar 98,7\% dan hanya 1,3\% memiliki asupan zat besi lebih. Hasil penelitian ini sama dengan hasil penelitian yang dilakukan oleh Fany, Salmiah dan Pakhri pada siswa Smu di Sulawesi Selatan yang menunjukan bahwa sebagian besar responden memiliki asupan zat besi kurang 
yaitu sebanyak 99,1\% dan hanya 0,9\% responden memiliki asupan zat besi lebih. ${ }^{10}$

Tingginya presentase asupan zat besi kurang pada remaja disebabkan kurangnya mengkonsumsi makanan sumber zat besi. Zat besi sangat penting bagi kaum remaja karena pertumbuhan yang cepat menyebabkan volume darah meningkat, demikian pula masa otot dan enzim-enzim. Pengaruh defisiensi zat besi terutama melalui kondisi gangguan fungsi hemoglobin yang merupakan alat transport oksigen yang diperlukan pada banyak reaksi metabolik tubuh. Pada remaja telah ditunjukan adanya hubungan erat antara kadar hemoglobin dan kesanggupan anak untuk belajar. Dikatakan bahwa pada kondisi anemia daya konsentrasi dalam belajar tampak menurun. Defisiensi zat besi, secara prinsip dapat diatasi antara lain dengan perubahan kebiasaan makan, karena anemia pada dasarnya disebabkan oleh kurangnya asupan zat besi dari makanan dan rendahnya bioavailibitas zat besi yang dikonsumsi, peningkatan kualitas menu makanan merupakan salah satu cara untuk meningkatkan asupan zat besi. ${ }^{8,10}$

Hasil penelitian untuk kadar hemoglobin menunjukan bahwa sebagian responden memiliki kadar hemoglobin normal yaitu $93,3 \%$ dan $6,7 \%$ memiliki kadar hemoglobin tidak normal. Hasil penelitian ini sama dengan hasil penelitian yang dilakukan Chusnul, Amalia dan Lisma pada remaja di Panarukan yang menunjukan bahwa sebagian besar responden memiliki kadar hemoglobin normal yaitu sebanyak 91,7\% dan $8,3 \%$ memiliki kadar hemoglobin tidak normal. ${ }^{11}$

Responden yang memiliki kadar hemoglobin tidak normal akan berdampak pada status imunitas dan fungsi kognitifnya. Kadar hemoglobin tidak normal sering disebut sebagai anemia. Anemia pada kelompok remaja dapat menimbulkan berbagai dampak antara lain menurunkan aktivitas yang berkaitan dengan kemampuan kerja fisik dan prestasi belajar. ${ }^{11}$

Analisis uji statistik pada penelitian ini menunjukan bahwa asupan protein tidak mempunyai hubungan yang bermakna dengan kadar hemoglobin pada Mahasiswa Program Studi Pendidikan Dokter Angkatan 2013 Fakultas Kedokteran Universitas Sam Ratulangi dengan nilai $\mathrm{p}=0,138$. Hasil ini berbeda dengan penelitian yang dilakukan oleh Sri Utami, Nelly dan Julia pada anak sekolah dasar di Kabupaten Bolaang yang mengatakan bahwa terdapat hubungan yang bermakna antara asupan protein dengan kejadian anemia. ${ }^{12}$ Kecukupan protein seseorang dipengaruhi oleh berat badan, usia dan mutu protein dalam pola konsumsi pangannya. Mutu protein makanan ditentukan salah satunya komposisi dan jumlah asam amino esensial. Protein hewani mengandung asam amino lebih lengkap dan banyak dibanding pangan nabati, karena itu protein hewani mempunyai mutu protein yang lebih baik dibandingkan protein nabati. $^{13}$

Analisis uji statistik pada penelitian ini menunjukan bahwa asupan zat besi tidak mempunyai hubungan yang bermakna dengan kadar hemoglobin pada Mahasiswa Program Studi Pendidikan Dokter Angkatan 2013 Fakultas Kedokteran Universitas Sam Ratulangi dengan nilai $\mathrm{p}=0,198$. Hasil ini berbeda dengan penelitian yang dilakukan oleh Sri Utami, Nelly dan Julia pada anak sekolah dasar di Kabupaten Bolaang yang mengatakan bahwa terdapat hubungan yang bermakna antara asupan zat besi dengan kejadian anemia. ${ }^{12}$

\section{SIMPULAN}

Asupan protein yang kurang sebesar $52,0 \%$, asupan protein cukup 16,05 dan asupan protein lebih sebesar 32,0\%. Asupan zat besi kurang sebesar $98,7 \%$ dan hanya $1,3 \%$ responden yang memiliki asupan zat besi lebih. Kadar hemoglobin normal sebesar 93,3\% dan 6,7\% responden memiliki kadar hemoglobin tidak normal. Tidak terdapat hubungan antara asupan protein dan zat besi dengan kadar hemoglobin pada Mahasiswa Program Studi Pendidikan Dokter Angkatan 2013 Fakultas Kedokteran Universitas Sam Ratulangi.

\section{SARAN}


Berdasarkan hasil yang didapatkan pada penelitian ini, maka penulis memberikan saran, sebaiknya perlu diperhatikan asupan makanan khususnya asupan protein dan zat besi. Juga perlu mengkonsumsi makanan yang beragam, bergizi dan seimbang karena asupan zat gizi mempunyai peran penting bagi tubuh. Pada penelitian selanjutnya diharapkan jumlah sampel dapat diperbanyak agar lebih dapat menggambarkan hubungan antara asupan protein dan zat besi dengan kadar hemoglobin serta melakukan penelitian lebih lanjut tentang asupan protein dan zat besi dengan kadar hemoglobin yang berhubungan dengan faktor-faktor lain.

\section{DAFTAR PUSTAKA}

1. I Dewa Nyoman Supariasa,dkk. Penilaian Status Gizi. Jakarta : EGC; 1995

2. Thobib S. Perbedaan Kadar Hemoglobin Pada Mahasiswa Universitas Jenderal Soedirman Yang Melakukan Olahraga Futsal Pada Siang Hari Dan Malam Hari. Skripsi. Purwokerto: Fakultas Kedokteran Dan Ilmu-Ilmu Kesehatan Jurusan Keperawtan Universitas Jenderal Soedirman; 2012

3. Muhammad Nur. Pengaruh suplementasi Fe terhadap kadar haemoglobin dan prestasi belajar anak sekolah dasar di Kecamatan Peukan Baro Kabupaten Pidie Nanggroe Aceh Darussalam. Tesis. Universitas Sumatera Utara; 2010

4. WHO [World Health Organization]. 2008. Worldwide Prevalence of Anemia19932005

5. Zarianis. The effect of iron-vitamin c and vitamin c supplementation on hemoglobin level of anemic elementary school children at sayung subdistrict demak district. (Tesis). Semarang. Universitas Diponegoro; 2006
6. Amelia R A, Aminuddin Syam, St Fatimah. Hubungan asupan energi dan zat gizi dengan status gizi santri putri yayasan pondok pesantren hidayatullah Makasar Sulawesi Selatan. Program Studi Ilmu Gizi. Fakultas Kesehatan Masyarakat. Universitas Hasanudin Makasar; 2013

7. Umasangaji Sadli M. Hubungan antara asupan energi protein, status gizi dengan kesegaran jasmani pada anggota klub tenis meja satelit dan salero star kota Ternate. Karya Tulis Ilmiah. Jurusan gizi. Politeknik Kesehatan. Ternate; 2012

8. Muchlisa, Citrakesumasari, Indriasari R. Hubungan asupan zat gizi dengan status gizi pada remaja putri di Fakultas Kesehatan Masyarakat Universitas Hasanudin Makasar tahun 2013. Program studi ilmu gizi. Fakultas Kesehatan Masyarakat. Universitas Hasanudin; 2013

9. Almatsier S. Prinsip Dasar Ilmu Gizi. Jakarta: Gramedia Pustaka Utama; 2009

10. Fanny L, Salmiah, Pahkri A. Tingkat asupan zat gizi dan status gizi iswa smu pgri Kabupaten Maros Provinsi Sulawesi Selatan. Media gizi pangan. IX edisi 1, 1519

11. Chusnul C, Ruhana A, Lisma M. Hubungan antara tingkat konsumsi makanan berserat dengan kadar hemoglobin pada remaja putri di Kecamatan Panarukan. Program Studi Pendidikan Dokter. Fakultas Kedokteran Universitas

12. Sri Utami, Nelly M, Julia R. Hubungan asupan zat gizi dengan kejadian anemia pada anak sekolah dasar di Kabupaten Bolaang Mongondow Utara. ejournal keperawatan. 2013; 1

13. Hardinsyah, Riyadi H, Napitupulu V. Kecukupan energi, protein, lemak dan karbohidrat. Departemen Gizi Masyarakat FEMA IPB. Departemen Gizi, Fakultas Kedokteran Universitas Indonesia; 2012 